\title{
Evaluating the Psychometric Properties of the Exercise Dependence Scale-Revised (EDS-R) in a Spanish Sample
}

\author{
Evaluación de las propiedades psicométricas \\ de la Escala Revisada de Dependencia del Ejercicio \\ (EDS-R) en una muestra española
}

Costanza Pujals ${ }^{1}$, José Ignacio Baile ${ }^{2} \bowtie$, María José González-Calderón ${ }^{3}$

\author{
${ }^{1}$ Autonomous University of Madrid, Madrid, Spain. \\ ${ }^{2}$ Open University of Madrid, Madrid, Spain. \\ ${ }^{3}$ Open University of Madrid, Madrid, Spain.
}

$\triangle$ Department of Psychology, Open University of Madrid (Udima). Carretera de La Coruña, km. 38'500. Vía de Servicio, 15. Collado Villalba, Madrid 28400, Madrid, España. Email: joseignacio.baile@udima.es

Received on: March 29th, $2017 \quad$ Revised on: February 3th, $2018 \quad$ Available online: April $1^{\text {st }}, 2018$
How to cite this article: Pujals, C., Baile, J. I., \& González-Calderón, M. J. (2018). Evaluating the Psychometric Properties
of the Exercise Dependence Scale-Revised (EDS-R) in a Spanish Sample. Pensando Psicología, 14(23). doi: https://doi.
org/10.16925/pe.v14i23.2267

\section{Abstract}

Introduction: There are several instruments to evaluate behavioural addictions. Furthermore, several specific scales have been developed to assess various aspects of exercise dependence. Nevertheless, in Spain there is a lack of specific instruments designed to assess exercise dependence.

Objective: This study aims to examine the psychometric properties of a Spanish version of the Exercise Dependence Scale-Revised.

Method: 175 university students who were regular exercisers $(M=59.11, S D=15.89)$ took part in the study. They were requested to complete the EDS-R, as well as the General Addiction Scale. The requirement to take part in the study was to exercise a minimum of four times per week.

Results: Findings provide initial support for the psychometric properties of the scale as its internal consistency (Cronbach's alpha: 0.907), and construct and convergent validity with the EAG-RC ( $r=.559$; $p<.001)$ are adequate. In addition, its structure did not need to be modified, as it kept the 21 original items from the American version. Factor analysis yielded a five-factor structure (tolerance, loss of control, continuity, intensity, and withdrawal symptoms) which differ from the ones obtained in the original (American) and French versions where seven factors were obtained. This correlated five-factor model explains $50 \%$ of the variance.

Conclusion: This Spanish EDS-R, which presents adequate psychometric properties, will provide researchers and clinicians with specific data on this screening tool for assessing exercise dependence. Further research is needed to confirm the current results and check its validity both in research and clinical practice.

Keywords: EDS-R, exercise dependence, factor analysis, psychometric properties. 


\title{
Evaluación de las propiedades psicométricas de la Escala Revisada de Dependencia del Ejercicio (EDS-R) en una muestra española
}

\begin{abstract}
Resumen
Introducción: existen varios instrumentos para evaluar las adicciones conductuales. Además, se han desarrollado varias escalas específicas para evaluar diversos aspectos de la dependencia del ejercicio. Sin embargo, en España faltan instrumentos específicos diseñados para evaluar la dependencia del ejercicio.

Objetivo: Este estudio tiene como objetivo examinar las propiedades psicométricas de una versión en español de la Escala Revisada de Dependencia del Ejercicio.

Metodología: 175 estudiantes universitarios, que se ejercitaban regularmente $(M=59,11, D E=15,89)$, participaron en el estudio. Se les solicitó completar la EDS-R y la Escala General de Adicción. El requisito para participar en el estudio fue ejercitarse como mínimo cuatro veces a la semana.

Resultados: los hallazgos brindan un soporte inicial para las propiedades psicométricas de la escala puesto que su consistencia interna (alfa de Cronbach: 0,907) y la validez de constructo y convergente con la EAG-RC $(r=0,559 ; p<0,001)$ son adecuadas. Además, su estructura no tuvo que modificarse ya que mantuvo los 21 ítems originales de la versión estadounidense. El análisis factorial arrojó una estructura de cinco factores (tolerancia, pérdida de control, continuidad, intensidad y síntomas de abstinencia) que difieren de los obtenidos en las versiones original (estadounidense) y francesa, en las que se obtuvieron siete factores. Este modelo correlacionado de cinco factores explica el $50 \%$ de la varianza.

Conclusión: esta EDS-R en español, que presenta propiedades psicométricas adecuadas, proporcionará a los investigadores y médicos clínicos datos específicos sobre esta herramienta de selección para evaluar la dependencia del ejercicio. Se necesitan más investigaciones para confirmar los resultados actuales y verificar su validez tanto en la investigación como en la práctica clínica.
\end{abstract}

Palabras clave: EDS-R, dependencia del ejercicio, análisis factorial, propiedades psicométricas.

\section{Avaliação das Propriedades Psicométricas da Escala Exercise Dependence Scale-Revised (EDS-R) em Versão Espanhola}

\begin{abstract}
Resumo
Introdução: existem vários instrumentos para avaliar vícios comportamentais. Além disso, diversas escalas específicas foram desenvolvidas para tratar de diferentes aspectos da dependência de exercícios físicos. No entanto, na Espanha existe uma falta de instrumentos desenhados especificamente para avaliar a dependência de exercícios físicos.

Objetivo: este estudo visa examinar as propriedades psicométricas de uma versão espanhol da escala Exercise Dependence Scale-Revised.

Metodologia: 175 estudantes universitários que se exercitam regularmente ( $M=59.11, S D=15.89)$ participaram do estudo. Foi solicitado que eles respondessem à escala EDs-R, bem como à escala General Addiction Scale. 0 requisito para participar da pesquisa era exercitar-se quatro vezes por semana, no mínimo.

Resultados: os resultados fornecem apoio inicial às propriedades psicométricas da escala como sua consistência interna (alfa de Cronbach: 0.907) e 0 construto e a validade convergente com 0 EAG-RC $(r=.559 ; p<.001)$ são adequados. Adicionalmente, sua estrutura não precisou ser modificada já que manteve os 21 itens originais da versão americana. A análise fatorial resultou em uma estrutura de cinco fatores (tolerância, perda do controle, continuidade, intensidade e sintomas de abstinência) que diferem dos fatores obtidos na versão original (americana) e na versão francesa, nas quais foram obtidos sete fatores. Esse modelo de cinco fatores correlacionados explica $50 \%$ da variância.

Conclusões: a versão espanhola do EDS-R, que apresenta propriedades psicométricas adequadas, fornecerá dados específicos sobre essa ferramenta de triagem para que pesquisadores e clínicos possam avaliar a dependência de exercício físico. Pesquisas adicionais são necessárias para confirmar os atuais resultados e revisar a sua validade tanto na pesquisa quanto na prática clínica.
\end{abstract}

Palavras-chave: EDS-R, dependência de exercícios físicos, análise fatorial, propriedades psicométricas. 


\section{Introduction}

Regular exercise and sport practice are leisure activities that promote physical, mental and social wellbeing. Nevertheless, taken to a compulsive, excessive level or practiced for merely aesthetic purposes, exercise can become harmful (Baile, González, Ramírez, \& Suárez, 2011; Guszkowska, 2012). In some cases, this excess could be regarded as exercise dependence or addictive exercise.

According to Terry, Szabo, and Griffiths (2004), the definitions of addiction and dependence have traditionally been associated with chemical substance abuse. However, they have recently been used to describe a large number of potentially addictive behaviours, such as gambling, internet use, video game-playing, sex, and even exercise.

Arbinaga (2004) suggests that the first mentions of exercise dependence can be found in Baekeland's work (1970) on the effect of one-month exercise deprivation on sleep patterns. Since then, numerous references to addictive exercise practices can be found in scientific literature, including running addiction (Glasser, 1976; Sachs \& Pargman, 1979), negative addiction (Morgan, 1979), fitness fanaticism (Little, 1979), obligatory running (Yates, Leehey, \& Shisslak, 1983), morbid exercising (Chalmers, Catalan, Day, \& Fairburn, 1985), compulsive exercise (Hauck \& Blumenthal, 1992), exercise addiction (Valenzuela \& Arriba-Palomero, 2017), and primary exercise dependence (Veale, 1995).

At present, there is no consensus on the definition of addictive exercise and its determining manifestations. Exercise dependence has been defined as a craving for leisure-time physical activity resulting in uncontrollable excessive exercise behaviour that generates negative physiological (e.g. overuse injuries, tolerance) and psychological symptoms (e.g. negative affect when unable to exercise) (Hausenblas \& Giacobbi, 2004; Petit \& Lejoyeux, 2013). Psychological studies also explain exercise addiction in terms of reward, habituation, social support, stress-relief, avoidance of withdrawal, and reduction of anxiety (Weinstein \& Weinstein, 2014). Besides, Ades and Lejoyeux (2003) stated that an addiction or dependence begins with the search for a pleasant feeling when exercising, which gradually leads to an obsession with its usual practice and even the exhibition of withdrawal symptoms when exercise cannot be conducted. Another feature of this anomalous behaviour would be the onset of tolerance, as more and more exercise is increasingly needed to get the same rewarding feeling, as well as dissatisfaction with what has been achieved, which may even lead to irritability, anxiety, and depression. It can be concluded that there is a need for consistent terminology as Szabo, Griffiths, de la Vega, Mervó, \& Demetrovics (2015) pointed out after a recent review of research on exercise addiction.

Veale (1995) considers that an important distinction between "primary exercise dependence" (PED) and "secondary exercise dependence" (SED) should be made as the latter seems to occur in conjunction with an eating disorder. Self-inflicted weight loss through diet is also a SED feature which is quite common between many men and women who engage in physical exercise. However, in PED the physical activity is an end in and of itself, whereas diet and weight loss are mainly used for improving athletic performance. To diagnose exercise addiction, Veale outlined the following operational criteria based on the chemical addiction model in DSM-III (American Psychiatric Association [APA], 1980) for what he called Primary Exercise Dependence (Veale, 1987, 1995):

- Self-inflicted weight loss by dieting as a means of improving performance.

- Narrowing of repertoire to stereotyped pattern of exercise with a regular schedule once or more daily.

- Salience with the individual giving increasing priority over other activities to maintain the pattern of activity.

- Increased tolerance to the amount of exercise performed over the years.

- Withdrawal symptoms related to a disorder of mood following the cessation of the exercise schedule (voluntary or compulsory).

- Relief or avoidance of withdrawal symptoms by further exercise.

- Subjective awareness of the compulsion to exercise.

- Rapid reinstatement of the previous pattern of exercise and withdrawal symptoms after a period of abstinence.

- Either the individual continues to exercise despite a serious physical disorder known to be caused, aggravated or prolonged by exercise, and is advised as such by a health professional, or the individual has arguments or difficulties with his/her partner, family, friends or occupation. 
Hausenblas and Symons-Downs (2002a) argued that Veale's criteria also followed the style of the criteria used in the Diagnostic and Statistical Manual of Mental Disorders (DSM-IV; APA, 1994) for "substance abuse".

Primary dependence exercise is related to several personality characteristics such as disordered eating patterns, high levels of harm avoidance, and low self-directness (Guidi, Clementi, \& Grandi, 2013).

Exercise dependence may have different kinds of antecedents: genetic (especially as far as the so-called extreme sports are concerned), educational, physiological (based on changes in body temperature), and psychological. The latter includes exercising as a means of "escaping" from serious daily distress and "coping with" a situation, so that the bigger the challenge is the greater the satisfaction and self-esteem obtained when achieving it (Griffiths, 1997).

The warning signals begin with the exercise dependent putting practising sports regularly before their personal or labour commitments, training to overexertion, making radical changes in diet, and suffering drops in the body's defence systems, respiratory difficulties, as well as social isolation and depression symptoms. Indeed, several studies have reported a substantially greater prevalence of risk for exercise addiction in elite athletes compared to those who exercise for leisure as Szabo et al. (2015) found out. A good example is that of Ironman participants, as approximately $30 \%$ of them belong to at-risk and symptomatic profiles, which could reflect maladaptive patterns of exercise (Magee, Buchanan, \& Barrie, 2016).

Few studies have analysed whether there are gender differences in physical dependence or not. Chapman and De Castro (1990) found there were no significant gender differences as far as this variable is concerned, although both men and women differed in the number of hours they spent running. Besides, according to Kjelsas, Berit, and Gunnar (2003), who studied a sample made up entirely of women, intense practice of physical exercise is mainly related to social life interference and withdrawal symptoms.

\section{Exercise dependence assessment}

It is considered that behavioural measures (type of exercise, frequency, duration, and intensity of physical activity, omitted activities, etc.) do not accurately assess exercise dependence because they fail to capture the psychological characteristics of dependence (Symons-Downs, Hausenblas, \& Nigg, 2004). Therefore, it would be more appropriate to use self-reported psychological questionnaires such as Likert scales.

There are several instruments to evaluate behavioural addictions, and many alcohol and drug addiction assessment scales. Furthermore, several specific scales have been developed to assess various aspects of exercise dependence. The limitation of using the latter lies in the fact that they are either too specific or multidimensional.

In Table 1, a selection of exercise dependence and addiction scales is presented, with information regarding their psychometric and assessment characteristics.

Out of these, the Exercise Dependence Scale (EDs; Hausenblas \& Symons-Downs, 2002b) stands out as it can be used both by researchers and clinicians as a screening tool for primary exercise dependence symptoms (Veale, 1995). Hausenblas and Symons-Downs developed this multidimensional scale of exercise dependence symptoms based on the DSM-IV criteria for substance dependence (APA, 1994), as well as on previous research. In addition, based on the abovementioned adopted criteria and the total score obtained on the scale, individuals can be classified as belonging to one of the following groups: (a) at risk for exercise dependence (scores from 105 to 126); (b) nondependent-symptomatics (scores from 63 to 104); or (c) nondependent-asymptomatics (scores from 21 to 62).

Confirmatory factor analysis carried out by Symons-Downs et al. (2004) converted the original 28-item scale (EDS) into a 21-item one (EDS-R) and supported a correlated seven-factor model. Adequate internal consistency and test-retest reliability for the scale as well as its validity were also evidenced.

In Spain, Brieva, Cabasés, and Gurpide (2001) have developed and validated a Spanish scale called The Ramón y Cajal General Addiction Scale (La Escala General de Adicción Ramón y Cajal; EGA-RC) that measures an individual's addiction level to all kinds of new addictions, excluding the abuse of common illegal substances. Nevertheless, in Spain there is a lack of specific instruments designed to assess exercise dependence. As Arbinaga and Caracuel (2007) argued, so far there have been few studies in Spanish which have aimed to study and analyse the main characteristics of the exercise dependence process. 
Table 1

Exercise dependence assessment instruments

\begin{tabular}{|c|c|c|}
\hline SCALE AND AUTHOR & ITEM, STRUCTURE, AND DESCRIPTION & $\begin{array}{l}\text { RELIABILITY } \\
\text { INDEX }\end{array}$ \\
\hline $\begin{array}{l}\text { Exercise Dependence Questionnaire } \\
\text { (EDQ; Ogden et al., 1997) }\end{array}$ & $\begin{array}{l}29 \text { items } \\
7 \text {-point Likert scale } \\
8 \text { subscales: social-occupational interference, positive reward, withdrawal } \\
\text { symptoms, exercise for weight control, insight into problem, exercise for } \\
\text { social reasons, exercise for health reasons and stereotyped behaviour }\end{array}$ & $\begin{array}{l}\text { Cronbach's } \\
\text { alpha }=.84\end{array}$ \\
\hline $\begin{array}{l}\text { Exercise Dependence Scale-Revised } \\
\text { (EDS-R; Symons Downs et al., 2004) }\end{array}$ & $\begin{array}{l}21 \text { items } \\
\text { 5-point Likert scale } \\
7 \text { subscales: Tolerance, withdrawal symptoms, continuance, time, reduc- } \\
\text { tion in other activities, lack of control and intention effects }\end{array}$ & $\begin{array}{l}\text { Cronbach's } \\
\text { alpha }=.90\end{array}$ \\
\hline $\begin{array}{l}\text { Exercise Addiction Inventory } \\
\quad(\text { EAI; Terry et al., 2004) }\end{array}$ & $\begin{array}{l}6 \text { items } \\
5 \text {-point Likert scale } \\
6 \text { subscales: Salience, conflict, mood modification, tolerance, withdrawal } \\
\text { and relapse }\end{array}$ & $\begin{array}{l}\text { Cronbach's } \\
\text { alpha }=.96\end{array}$ \\
\hline $\begin{array}{l}\text { Escala de Adicción al Entrenamiento } \\
\text { (EAE; Ruiz-Juan, Zarauz, \& Arbinaga, } \\
\text { 2013) }\end{array}$ & $\begin{array}{l}11 \text { items } \\
7 \text {-point Likert scale } \\
4 \text { subscales: Pleasure and relaxation, tolerance, lack of control, abstinence } \\
\text { and craving }\end{array}$ & $\begin{array}{l}\text { Cronbach's } \\
\text { alpha }=.94\end{array}$ \\
\hline
\end{tabular}

Note: Compiled by the authors

\section{Purpose of the Study}

The main objective of the present paper is to make up for the lack of research on exercise dependence in Spain, specifically its assessment aspect, by adapting and examining the psychometric properties of the EDS- $\mathrm{R}$ in a Spanish sample, as different studies have provided evidence for its validity and reliability when analysed in different populations.

\section{Method}

\section{Participants}

One hundred and seventy-five male and female volunteer students recruited from the Physical Education Faculty in the UAM University in Madrid (Spain) who practiced exercise regularly took part in the study ( $M$ age $=25.9$ years; $S D=7.49$ ). Sixty-four percent of the participants were male and most of them were Caucasian. The only requirement to take part in the study was to exercise a minimum of four times per week. The average weekly time committed to physical activity was 8.7 hours $(S D=6.29)$. None of the subjects received any kind of compensation for participating in the study, and all of them gave informed consent.

The sample size was similar to that employed in the sports research field, as can be seen in Terry et al.'s work (2004) using 200 subjects to validate the EAI scale or in Buccini's research (1992) (as cited in Hausenblas and Symons-Downs, 2002a) where 120 participants helped validate the Running Dependence Scale.

\section{Materials}

\section{Exercise Dependence Scale-Revised (EDS-R;} Symons-Downs et al., 2004). The EDS consists of the following seven subscales: tolerance, withdrawal, continuance, lack of control, reduction in other activities, time, and intention effects. Subjects must indicate their endorsement of each of the 21 items on a 6-point Likert scale $(1=$ never and $6=$ always $)$. A higher score reveals more exercise dependence symptoms. The total score is obtained from the sum of all items. The EDS-R has been successfully adapted to other European populations (Allegre \& Therme, 2008; Demetrovics \& Kurimay, 2008; Kern, 2007). This aspect together with its short length led us to examine this instrument in a Spanish sample.

The Ramón y Cajal General Addiction Scale (EAG-RC; Brieva et al., 2001). The EAG-RC consists of eleven items structured in the following four addiction-related dimensions: withdrawal, tolerance, lack of control, and craving. Subjects must answer a 6-point Likert scale ranging from 1 (absolutely disagree) to 7 (absolutely agree), except for items 1,3 , and 10, which are inversely rated. The total score, which is obtained 
from the addition of every single item, ranges from 11 to 77. In this research, the EAG-RC has been used as a reference scale to examine the convergent validity of the EDS-R. Although it assesses general addiction, it was selected because there was no other specific scale available in Spanish to assess exercise dependence, and because it evaluates those dimensions that have been considered to necessarily take place in the ongoing process of addiction. It can be used to assess various addictions, such as drugs, gambling, alcohol, sex, computer use or physical exercise, due to the way each item is presented; in fact, it has already been used to study physical exercise addiction (Arbinaga \& Caracuel, 2007).

It should also be noted that, according to Arbinaga and Caracuel (2007), this scale may become a valid and easy-to-apply instrument in the assessment of the specific addiction to physical exercise, as it showed a good convergent validity with external criteria for physical exercise $\left(r^{2}=.69, p<.01\right)$.

\section{Procedure}

The standard procedures for the study of the psychometric properties of Likert scales (Barbero, 1993) were used in the current research. They consisted of a series of five independent and sequential steps: Step 1 (Instrument selection and its translation into Spanish); Step 2 (Item refinement through experts' judgment); Step 3 (Discriminant power analysis); Step 4 (Reliability analysis); and Step 5 (Construct and Convergent Validity analysis). Firstly, researchers contacted the Sports Service in the UAM University and accessed five gym trainers there. Then, participants were requested to complete the questionnaires anonymously in each trainer's classroom during their lecture time and required $15 \mathrm{~min}$ utes to finish. Prior to participation, each volunteer provided informed consent.

Data analysis was performed using the software sPss 15.0 for Windows.

\section{Results}

\section{Step 1. Instrument Slection and its Translation in Spanish}

At the beginning of the study, a thorough search of the scientific literature was conducted, but was unsuccessful in locating a validated instrument in Spanish to assess physical exercise dependence. Therefore, it was decided that the available international instruments should be examined and the best one be translated to be used with the Spanish population.

The Exercise Dependence Scale-Revised (EDSR) was considered the most appropriate one as it was quite specific, had good psychometric properties, and had been previously adapted to be used with other European populations.

The first step taken was to use forward and backward blind translations. The latter is the most common and highly recommended procedure for establishing semantic equivalence, and ensuring the validity of the target culture version. To accomplish this aim, the initial translation was completed by bilinguals not associated with the project or the exercise dependence field. A bilingual Spanish translator, knowledgeable of the English-speaking culture, translated the EDS-R items. Secondly, a bilingual English translator back translated the scale into Spanish. The objective in selecting non-professional translators was to guard against language not commonly understood by the average Spanish citizen.

Afterwards, the translated version of the EDS-R was administered to twenty people who regularly practiced physical exercise, and showed similar socio-demographic characteristics to those of the final sample. In this pilot test, the subjects were requested to evaluate the comprehension and readability of the Spanish scale, as well as to propose any terminological changes.

\section{Step 2. Item Refinement Through Experts' Judgment}

Once the pilot test was carried out, the EDS-R items were analysed by three prestigious Spanish specialists in the sports field and its related disorders, two university professors who taught sports psychology, and one sports trainer. This analysis led to a first approach to the study of the construct validity of the scale, and to make some terminological changes. To achieve this aim, these experts, who were familiar with exercise dependence terminology, were requested to indicate whether the items were valid to assess physical exercise dependence in the Spanish population, and to propose any terminological readjustments. Taking their answers into account, none of the originally proposed items was omitted, as they were all considered to be valid. Nonetheless, as far as several specific items are concerned, some semantic 
and grammatical changes were made. In addition, the scale presentation was also modified. The final version of this Spanish EDS-R scale can be seen in the Appendix.

\section{Step 3. Discriminant Analysis}

Following Barbero (1993), and Martínez-Arias (1995), an item refinement process was executed by means of a corrected item-scale correlation which consists of correlating each item with all the scale items, excluding itself. After examining the corrected correlations, none of the items was deleted, as every correlation value was higher than .20. The results of this study can be verified in Table 2 .

Table 2

Corrected Item-scale Correlation for a

Spanish Version of the EDS-R

\begin{tabular}{cc}
\hline EDS-R item & Corrected Item-Total Scale correlation \\
\hline item1 & .43 \\
item2 & .53 \\
item3 & .54 \\
item4 & .51 \\
item5 & .52 \\
item6 & .60 \\
item7 & .60 \\
item8 & .40 \\
item9 & .63 \\
item10 & .63 \\
item11 & .55 \\
item12 & .55 \\
item13 & .56 \\
item14 & .55 \\
item15 & .38 \\
item16 & .61 \\
item17 & .63 \\
item18 & .51 \\
item19 & .35 \\
item20 & .51 \\
item21 & .68 \\
\hline
\end{tabular}

Note: Compiled by the authors

Consequently, the final version to be used to examine the scale reliability and convergent validity was definitely composed of the 21 initial items (see Appendix).

\section{Step 4. Internal Consistency}

This overall Spanish EDS-R Cronbach's alpha coefficient was .91 , pointing out a high internal consistency according to the recommended alpha for established instruments.

The Cronbach's alpha coefficients for each factor, which ranged from .80 (lack of control) to .87 (withdrawal), are all of them above the satisfactory value of .70 (see table 3 ).

The internal consistency of the scale was also assessed by means of the split half method, consisting of the correlation of two sets of scores obtained from the EDS-R, one from odd items and another one from even items. The obtained value using this method was also considered quite acceptable $(r=.85 ; p<.001)$.

\section{Step 5. Construct and Convergent Validity}

To examine construct validity, a principal component factor analysis (varimax rotation with Kaiser) was performed. The main aim was to check whether the items tended to consistently group in factors related to the "exercise dependence" construct.

This exploratory factor analysis (EFA) yielded a five-factor solution that together explained $65.69 \%$ of the variance, which support the appropriate construct validity of the scale. Items-Factor loading for each factor ranged from 0.51 to 0.87 . Overall, these analyses indicated that the following five factors were underlying participant's responses to EDS-R and that these factors were internally consistent.

Factor 1: Tolerance (items 3, 6, 13, 17, and 20). It explains $35.88 \%$ of the variance and consists of either a need for increased amounts of exercise to achieve the desired effect or a diminished effect with continued use of the same amount of exercise.

Factor 2: Lack of control (items 4, 5, 10, 11, 12, 18 , and 19). It explains $10.27 \%$ of the variance and refers to a persistent desire or unsuccessful effort to cut down or control exercise.

Factor 3: Withdrawal (items 1, 8, and 15). It explains $7.51 \%$ of the variance and is manifested by either the characteristic withdrawal symptoms for exercise (e.g. anxiety, fatigue) or exercising the same (or closely related) amount to relieve or avoid withdrawal symptoms.

Factor 4: Intention effects (items 7, 14, and 21). It explains $6.49 \%$ of the variance and refers to the fact that exercise is often taken in larger amounts or over a longer period than intended. 
Factor 5: Continuance (items 2, 9, and 16). It explains $5.54 \%$ of the variance. According to this construct, exercise is continued despite knowledge of having a persistent or recurrent physical or psychological problem that is likely to have been caused or exacerbated by the exercise (e. g. continued running despite injury).

The naming of the different factors was taken from the names of such dimensions of the American version.
The EFA yielded 5 factors instead of seven, as the first five factors explained $35.88 \%, 10.274 \%, 7.51 \%$, $6.49 \%$, and $5.54 \%$ of the variance, respectively. Items 6,13 , and 20, which load in the "Time" factor in the American version of the EDS-R, load in the Tolerance factor in the Spanish version. Moreover, items 5, 12, and 19 , which load in the "Reduction in other activities" factor in the original version, load in the Lack of control one in this Spanish version of the EDS-R.

Table 3

Items, Factor Loadings, and Internal Consistency Reliabilities for a Spanish Version of the EDS-R

\begin{tabular}{|c|c|c|c|c|c|}
\hline \multirow{2}{*}{$\begin{array}{l}\text { Item Description } \\
\text { (Item number) }\end{array}$} & \multicolumn{5}{|c|}{ Factor } \\
\hline & Tolerance & Lack of Control & Withdrawal & Intention Effects & Continuance \\
\hline $\begin{array}{l}\text { I continually increase my exercise intensity to } \\
\text { achieve the desired effect/benefits (item } 3 \text { ) }\end{array}$ & .76 & .20 & .18 & -.02 & .13 \\
\hline I spend a lot of time exercising (item 6) & .73 & .24 & -.02 & .25 & .14 \\
\hline $\begin{array}{l}\text { I spend most of my free time exercising (item } \\
\text { 13) }\end{array}$ & .70 & .17 & .07 & .19 & .16 \\
\hline $\begin{array}{l}\text { I continually increase my exercise duration to } \\
\text { achieve the desired effect/benefits (item 17) }\end{array}$ & .61 & .43 & .14 & .17 & .07 \\
\hline $\begin{array}{l}\text { A great deal of time is spent exercising (item } \\
\text { 20) }\end{array}$ & .71 & -.04 & .01 & .30 & .24 \\
\hline $\begin{array}{l}\text { I am unable to reduce how long I exercise (item } \\
\text { 4) }\end{array}$ & .17 & .66 & .15 & .09 & .09 \\
\hline $\begin{array}{l}\text { I would rather exercise than spend time with } \\
\text { family/friends (item 5) }\end{array}$ & .21 & .59 & .02 & .02 & .32 \\
\hline $\begin{array}{l}\text { I continually increase my exercise frequency to } \\
\text { achieve the desired effect/benefits (item 10) }\end{array}$ & .44 & .51 & .16 & .25 & .09 \\
\hline $\begin{array}{l}\text { I am unable to reduce how often I exercise } \\
\text { (item 11) }\end{array}$ & .08 & .70 & .06 & .34 & .06 \\
\hline $\begin{array}{l}\text { I think about exercise when I should be concen- } \\
\text { trating on school/work (item 12) }\end{array}$ & .23 & .52 & .06 & .16 & .29 \\
\hline $\begin{array}{l}\text { I am unable to reduce how intense I exercise } \\
\text { (item 18) }\end{array}$ & .31 & .64 & -.02 & .05 & .12 \\
\hline $\begin{array}{l}\text { I choose to exercise so I can get out of spending } \\
\text { time with family/friends (item 19) }\end{array}$ & -.26 & .52 & .28 & .20 & .18 \\
\hline I exercise to avoid feeling irritable (item 1) & .20 & .09 & .85 & .04 & .06 \\
\hline I exercise to avoid feeling anxious (item 8) & .01 & .15 & .87 & .11 & .08 \\
\hline I exercise to avoid feeling tense (item 15) & .06 & .05 & .87 & .09 & .13 \\
\hline I exercise longer than I intend (item 7) & .27 & .20 & .09 & .82 & .10 \\
\hline I exercise longer than I expect (item 14) & .19 & .13 & .16 & .84 & .11 \\
\hline I exercise longer than I plan (item 21) & .24 & .37 & .05 & .71 & .25 \\
\hline $\begin{array}{l}\text { I exercise despite recurring physical problems } \\
\text { (item 2) }\end{array}$ & .25 & .08 & .18 & .06 & .83 \\
\hline I exercise when injured (item 9) & .28 & .34 & .05 & .12 & .70 \\
\hline
\end{tabular}




\begin{tabular}{lccccc}
\hline \multicolumn{1}{c}{$\begin{array}{c}\text { Item Description } \\
\text { (Item number) }\end{array}$} & \multicolumn{5}{c}{ Factor } \\
\cline { 2 - 6 } & Tolerance & Lack of Control & Withdrawal & Intention Effects & Continuance \\
\hline $\begin{array}{l}\text { I exercise despite persistent physical problems } \\
\text { (item 16) }\end{array}$ & .07 & .33 & .11 & .28 & .76 \\
Mean score & 3.44 & 2.61 & 2.67 & 2.57 & 2.58 \\
Standard Deviation & 1.24 & 1.21 & 1.34 & 1.25 & 1.38 \\
\% of explained variance & $35.88 \%$ & $10.27 \%$ & $7.51 \%$ & $6.49 \%$ & $5.54 \%$ \\
$\begin{array}{l}\text { Internal consistency reliability (Cronbach's } \\
\text { alpha) }\end{array}$ & .84 & .80 & .87 & .86 & .83 \\
\hline
\end{tabular}

Extraction method: principal component analysis Rotation method: Varimax with Kaiser Normalization

Note: Compiled by the authors

To increase the uniqueness of each factor, the following criteria recommendations by Martínez-Arias (1995) were followed: a) Items with lower loadings of .40 were deleted; and b) each item was assigned to a single factor, the one with the highest loading value on its respective factor. Factor structure and item loadings can be seen in Table 3 .

Convergent validity was assessed by examining the relationship between the EDS-R and The Ramón y Cajal General Addiction Scale (EGA-RC). The latter was used as an external criterion. The correlation coefficient between them was statistically significant $(r=.56 ; p<.001)$.

\section{Discussion and Conclusions}

This article presented results on five studies or steps examining a Spanish version of the EDS-R. Findings provide initial support for the psychometric properties of the scale as its internal consistency, and construct and convergent validity are adequate. In addition, its structure did not need to be modified, as it kept the 21 original items from the American version.

The study findings offer support for the EDS-R as a reliable measure of exercise dependence in a Spanish sample, given that Cronbach's alpha (.91) exceeds .70, the value considered adequate for this kind of scales (Restrepo \& García, 2001), and it is also consistent with the results obtained by Kern (2007) with the French adaptation of the EDS-R $(\alpha=.87)$, and even slightly higher than that obtained by Hausenblas and Giacobbi (2004) with the original American version $(\alpha=.90$; see table 4$)$.

It was also consistent with previous research on exercise scales within the sports psychology field, such as the Exercise Addiction Inventory by Griffiths,
Szabo, and Terry $(2005 ; \alpha=.96)$ or the Exercise Dependence Questionnaire by Ogden, Veale, and Summers $(1997 ; \alpha=.84)$.

Support for the convergent validity of the scale in this study was evidenced, as the obtained correlation value $(r=.56 ; p<.001)$ can be considered appropriate. To examine it, The Ramón y Cajal General Addiction Scale was used, as there was no other specific Spanish validated instrument to assess physical exercise dependence.

Factor analysis yielded a five factor structure (tolerance, loss of control, continuity, intensity, and withdrawal symptoms) which differ from the ones obtained in the original (American) and French versions, where seven factors were obtained: the five previously mentioned dimensions, as well as a) "reduction in other activities", composed of items 5, 12, and 19, which refers to the giving up of social or labour activities in detriment of training (in this Spanish version those items were included in the "lack of control" factor), and b) "time", composed of items 6, 13, and 20, which refers to the amount of time someone spends exercising (in this Spanish version those items were included in the "tolerance" factor). Table 4 shows a comparative chart of the factor structure of the three versions of the EDS-R, the original American, the French, and the Spanish versions.

As far as the internal consistency of most factors is concerned, it can be concluded that this Spanish version and the French one are comparable. Furthermore, both are slightly different from the American version, as the latter shows higher reliability indexes. It may also be noted that the "reduction in other activities" factor, which does not turn up in this Spanish version of the EDS-R, is the factor which has a significantly lower internal consistency in the 
American and French versions, .67 and .54 respectively, values slightly above those estimated as satisfactory by Nunnally (1978) [as cited in Kern, 2007], who established that alpha internal consistency coefficients lower than .50 should not be considered adequate.

Table 4

Factor Structure and Internal Consistency of the American, French and Spanish Versions of the Exercise Dependence Scale-Revised (EDS-R)

\begin{tabular}{|c|c|c|}
\hline $\begin{array}{c}\text { EDS-R } \\
\text { VERSION }\end{array}$ & $\begin{array}{c}\text { FACTOR } \\
\text { STRUCTURE }\end{array}$ & $\begin{array}{c}\text { INTERNAL } \\
\text { CONSISTENCY } \\
\text { (CRONBACH'S } \\
\text { ALPHA) }\end{array}$ \\
\hline \multirow{6}{*}{ SPANISH } & 1- Tolerance & .84 \\
\hline & 2- Lack of Control & .79 \\
\hline & 3- Withdrawal & .86 \\
\hline & 4- Intention Effects & .85 \\
\hline & 5- Continuance & .83 \\
\hline & Total Score & 0.91 \\
\hline \multirow{8}{*}{ AMERICAN } & 1- Tolerance & .78 \\
\hline & 2- Lack of Control & .82 \\
\hline & 3- Withdrawal & .93 \\
\hline & 4- Intention Effects & .92 \\
\hline & 5- Continuance & .89 \\
\hline & 6- Time & .88 \\
\hline & $\begin{array}{l}\text { 7- Reduction in Other } \\
\text { Activities }\end{array}$ & .67 \\
\hline & Total Score & 0.90 \\
\hline \multirow{8}{*}{ FRENCH } & 1- Tolerance & .81 \\
\hline & 2- Lack of Control & .75 \\
\hline & 3- Withdrawal & .73 \\
\hline & 4- Intention Effects & .83 \\
\hline & 5- Continuance & .80 \\
\hline & 6- Time & .78 \\
\hline & $\begin{array}{l}\text { 7- Reduction in Other } \\
\text { Activities }\end{array}$ & .54 \\
\hline & Total Score & 0.87 \\
\hline
\end{tabular}

Note: Compiled by the authors

In summary, it can be noted that the goal of increasing knowledge in the field of exercise dependence in Spain that has been achieved as this Spanish EDS-R, which presents adequate psychometric properties, will provide researchers and clinicians with specific data on this screening tool for assessing exercise dependence.

Future studies, including a larger participant sample, are needed to further examine the psychometric properties of the scale, and to make more valid individual and group comparisons. Clinical validation studies employing pathological subjects should also be carried out in order to establish its cut off points.

\section{References}

Ades, J., \& Lejoyeux, M. (2003). Las nuevas adicciones: internet, sexo, juego, deporte, compras, trabajo y dinero. Barcelona: Kairós.

Allegre, B., \& Therme, P. (2008). Confirmative Study of a French Version of the Exercise Dependence Scale-Revised with a French population. Encephale, 5, 490-495. doi: 10.1016/j.encep.2007.08.004

American Psychiatric Association (1980). Diagnostic and Statistical Manual of Mental Disorders (DSM-III). Washington, DC: Masson.

American Psychiatric Association (1994). Diagnostic and Statistical Manual of Mental Disorders (DSM-IV). Washington, DC: Masson.

Arbinaga, F. (2004). Dependencia del ejercicio físico. Cuadernos de Medicina Psicosomática y Psiquiatría de Enlace, 71/72, 24-32.

Arbinaga, F., \& Caracuel, J. C. (2007). Dependencia del ejercicio físico en fisioculturistas competidores evaluada mediante la Escala de Adicción General Ramón y Cajal. Universitas Psychologica, 6(3), 549-557.

Baekeland, F. (1970). Exercise Deprivation: Sleep and Psychological Reactions. Archives of General Psychiatry, 22, 365-369. doi: 10.1001/archpsyc.1970.01740280077014

Baile, J. I., González, A., Ramírez, C., \& Suárez, P. (2011). Imagen corporal, hábitos alimentarios y hábitos de ejercicio físico en hombres usuarios de gimnasio y hombres universitarios no usuarios. Revista de Psicología del Deporte, 20(2), 353-366.

Barbero, M. I. (1993). Psicometría II. Métodos de elaboración de escalas. Madrid: UNED.

Brieva, R., Cabasés, S., \& Gurpide, M. A. (2001). Desarrollo, validez y seguridad de una escala de adicción general. Un estudio preliminar. Actas Españolas de Psiquiatría, 29(6), 368-373.

Chalmers, J., Catalan, J., Day, A., \& Fairnburn, C. (1985). Anorexia Nervosa Presenting as Morbid Exercising. Lancet, 1,286-287.doi:10.1016/S0140-6736(85)91065-7 
Chapman, C.L., \& De Castro, J. M. (1990). Running Addiction: Measurement and Associated Psychological Characteristics. The Journal of Sports Medicine and Physical Fitness, 30, 283-290.

Demetrovics, Z., \& Kurimay, T. (2008). Exercise Addiction: A Literature Review. Psychiatria Hungarica, 23, 129-141.

Glasser, W. (1976). Positive Addiction. New York: Harper.

Griffiths, M. (1997). Exercise Addiction: A Case Study. Addiction Research, 5, 161-168. doi: 10.3109/1606635 9709005257

Griffiths, M., Szabo, A., \& Terry, A. (2005). The Exercise Addiction Inventory: A Quick and Easy Screening Tool for Health Practitioners. British Journal of Sports Medicine, 39, 346. doi: 10.1136/bjsm.2004.017020

Guidi, J., Clementi, C., \& Grandi, S. (2013). Psychological Distress and Personality Characteristics Among Individuals with Primary Exercise Dependence. Rivista di Psichiatria, 48(2), 121-129. doi: 10.1708/1272.14036

Guszkowska, M. (2012). Exercise Dependence-symptoms and Mechanisms. Psychiatria Polska, 46(5), 845-856.

Hauck, E.R., \& Blumenthal, J. A. (1992). Obsessive and Compulsive Traits in Athletes. Sports Medicine, 14, 215-227. doi: 10.2165/00007256-199214040-00001

Hausenblas, H. A., \& Giacobbi, P.R. (2004). Relationship Between Exercise Dependence Symptoms and Personality. Personality and Individual Differences, 36, 1265 1273. doi: 10.1016/S0191-8869(03)00214-9

Hausenblas, H.A., \& Symons-Downs, D. (2002a). Exercise Dependence: A Systematic Review. Psychology of Sport and Exercise, 3, 89-123. doi: 10.1016/S1469-0292 (00)00015-7

Hausenblas, H. A., \& Symons-Downs, D. (2002b). How Much is Too Much? The Development and Validation of The Exercise Dependence Scale. Psychology and Health, 17, 387-404. doi: 10.1080/0887044022000004894

Kern, L. (2007). Validation de l'adaptation française de l'échelle de dépendence à l'exercise physique: 1'EDS-R. Pratiques psychologiques, 13, 425-441. doi: 10.1016/j. prps.2007.06.003

Kjelsas, E., Berit, L.A., \& Gunnar, K.G. (2003). La dependencia del ejercicio fisico en la mujer físicamente activa. The European Journal of Psychiatry, 17, 135-145. doi:10.4321/S1579-699X2003000300002

Little, J. C. (1979). Neurotic Illness in Fitness Fanatics. Psychiatric Annals, 9, 49-56.

Magee, C.A., Buchanan, I., \& Barrie, L. (2016). Profiles of Exercise Dependence Symptoms in Ironman Participants. Psychology of Sport and Exercise, 24, 48-55. doi: 10.1016/j.psychsport.2016.01.005
Martínez-Arias, R. (1995). Psicometría: teoría de los tests psicológicos y educativos. Madrid: Editorial Síntesis.

Morgan, W.P. (1979). Negative Addiction in Runners. The physician and Sportsmedicine, 7, 57-71. doi: 10.1080/ 00913847.1979.11948436

Nunnally, J. C. (1978). Psychometric Theory. New York: McGraw-Hill.

Ogden, J., Veale, D., \& Summers, Z. (1997). The Development and Validation of The Exercise Dependence Questionnaire. Addiction research, 5, 343-356. doi:10.3109/16066359709004348

Petit, A., \& Lejoyeux, M. (2013). Exercise Addiction. Revue Médicale de Liège, 68 (5-6), 331-339.

Restrepo, C. G., \& García, M. B. O. (2001). Adaptación y validación de escalas. In A. R. Morales, C. G. Restrepo, \& D. L. Trujillo (Eds), Investigación clínica: Epidemiología clínica aplicada (pp 63-81). Bogotá: Pontificia Universidad Javeriana.

Ruiz-Juan, F., Zarauz, A., \& Arbinaga, F. (2013). Validación de la Escala de Adicción al Entrenamiento (EAE) en atletas veteranos. Adicciones, 25(4), 309-320. doi: 10.20882/adicciones.32

Sachs, M. L., \& Pargman, D. (1979). Running Addictions: A Depth Interview Approach. Journal of Sport Behaviour, 2, 143-155.

Symons-Downs, D., Hausenblas, H. A., \& Nigg, C. R. (2004). Factorial Validity and PsychometricExamination of The Exercise Dependence Scale-Revised. Measurement in Physical Education and Exercise Science, 8(4), 183-201.

Szabo, A., Griffiths, M.D., de la Vega, R., Mervó, B., \& Demetrovics, Z. (2015). Methodological and Conceptual Limitations in Exercise Addiction Research. Yale Journal of Biology and Medicine, 88(3), 303-308.

Terry, A., Szabo, A., \& Griffiths, M. (2004). The Exercise Addiction Inventory: New Brief Screening Tool. Addiction Research and Theory, 12, 489-499. doi:10.1 080/16066350310001637363

Valenzuela, P. L., \& Arriba-Palomero, F. (2017). Riesgo de adicción al ejercicio en triatletas hombres amateur varones y su relación con variables de entrenamiento. Revista Internacional de Ciencias del Deporte, 13(48), 162-171. doi: 10.5232/ricyde2017.04806

Veale, D. (1987). Exercise Dependence. British Journal of Addiction, 82, 735-740. doi:10.1055/s-2007-1024745

Veale, D. (1995). Does Primary Exercise Dependence Really Exist? In J. Annett, B. Cripps, \& H. Steinberg (Eds), Exercise Addiction: Motivation for participation in sport and exercise (pp 1-5). Leicester, UK: British Psychological Society. 
Weinstein, A., \& Weinstein, Y. (2014). Exercise Addiction-diagnosis, Bio-psychological Mechanisms and Treatment Issues. Current Pharmaceutical Design, 19, 1-8. doi: 10.2174/13816128113199990614
Yates, A., Leehey, K., \& Shisslak, C. M. (1983). URNG-An Analogue of Anorexia? New England Journal of Medicine, 308(5), 251-255. 


\section{APPENDIX. Escala de Dependencia del Ejercicio Físico-Revisada \\ (Pujals, Baile, and González version of the EDs-R; 2013)}

\begin{tabular}{|c|c|c|c|c|c|c|}
\hline ÍTEMS & NUNCA & $\begin{array}{c}\text { CASI } \\
\text { NUNCA }\end{array}$ & $\begin{array}{l}\text { ALGUNA } \\
\text { VEZ }\end{array}$ & $\begin{array}{l}\text { BASTANTES } \\
\text { VECES }\end{array}$ & $\begin{array}{c}\text { CASI } \\
\text { SIEMPRE }\end{array}$ & SIEMPRE \\
\hline \multicolumn{7}{|l|}{ 1. Hago ejercicio para evitar sentirme irritado } \\
\hline \multicolumn{7}{|l|}{$\begin{array}{l}\text { 2. Hago ejercicio a pesar de tener problemas físicos } \\
\text { recurrentes }\end{array}$} \\
\hline \multicolumn{7}{|l|}{$\begin{array}{l}\text { 3. Incremento continuamente la intensidad del ejerci- } \\
\text { cio para lograr los efectos (o beneficios) deseados }\end{array}$} \\
\hline \multicolumn{7}{|l|}{$\begin{array}{l}\text { 4. Soy incapaz de reducir el tiempo que dedico al } \\
\text { ejercicio }\end{array}$} \\
\hline \multicolumn{7}{|l|}{$\begin{array}{l}\text { 5. Prefiero estar haciendo ejercicio en lugar de pasar } \\
\text { ese tiempo con mi familia o amigos }\end{array}$} \\
\hline \multicolumn{7}{|l|}{ 6. Dedico mucho tiempo al ejercicio físico } \\
\hline \multicolumn{7}{|l|}{ 7. Hago más ejercicio del que pretendo } \\
\hline \multicolumn{7}{|l|}{ 8. Hago ejercicio para evitar sentirme ansioso } \\
\hline \multicolumn{7}{|l|}{ 9. Hago ejercicio cuando estoy lesionado } \\
\hline \multicolumn{7}{|l|}{$\begin{array}{l}\text { 10. Aumento continuamente el número de veces que } \\
\text { hago ejercicio para lograr los efectos (o beneficios) } \\
\text { deseados }\end{array}$} \\
\hline \multicolumn{7}{|l|}{$\begin{array}{l}\text { 11. No consigo reducir la frecuencia con que hago } \\
\text { ejercicio }\end{array}$} \\
\hline \multicolumn{7}{|l|}{$\begin{array}{l}\text { 12. Estoy pensando en el ejercicio físico cuando debe- } \\
\text { ría estar concentrado en mis estudios o trabajo }\end{array}$} \\
\hline \multicolumn{7}{|l|}{$\begin{array}{l}\text { 13. Dedico la mayor parte de mi tiempo libre a hacer } \\
\text { ejercicio }\end{array}$} \\
\hline \multicolumn{7}{|l|}{ 14. Hago más ejercicio del que espero } \\
\hline \multicolumn{7}{|l|}{ 15. Hago ejercicio para evitar sentirme tenso } \\
\hline \multicolumn{7}{|l|}{$\begin{array}{l}\text { 16. Hago ejercicio a pesar de mis continuos problemas } \\
\text { físicos }\end{array}$} \\
\hline \multicolumn{7}{|l|}{$\begin{array}{l}\text { 17. Aumento continuamente la duración del ejercicio } \\
\text { para lograr los efectos (o beneficios) deseados }\end{array}$} \\
\hline \multicolumn{7}{|l|}{$\begin{array}{l}\text { 18. Soy incapaz de reducir la intensidad del ejercicio } \\
\text { que practico }\end{array}$} \\
\hline \multicolumn{7}{|l|}{$\begin{array}{l}\text { 19. Hago ejercicio para evitar estar con mi familia o } \\
\text { mis amigos }\end{array}$} \\
\hline \multicolumn{7}{|l|}{$\begin{array}{l}\text { 20. Gran parte de mi tiempo lo gasto haciendo ejerci- } \\
\text { cio físico }\end{array}$} \\
\hline 21. Hago más ejercicio del que planifico & & & & & & \\
\hline
\end{tabular}

